\title{
Buffalo Rock
}

\author{
by Ona Lacy Hunter, Springfield, Missouri
}

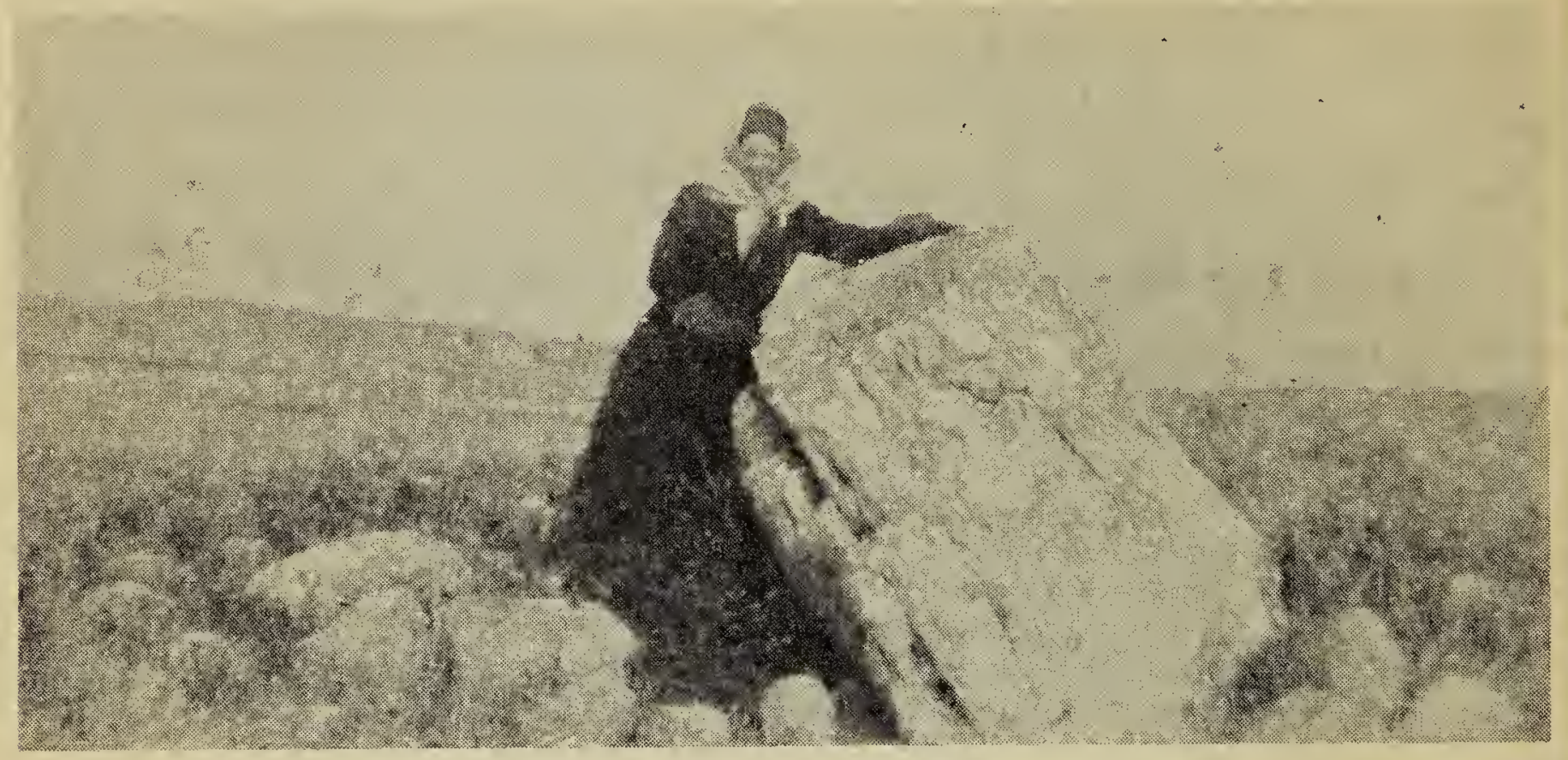

Eye-catching on the undulating prairie of our homestead situated three miles north-west of Ruthilda, Saskatchewan, was an enormous white rock, known by all the oldtimers as Buffalo Rock. Being near the main road, it served as a signpost for passers-by. We were proud of the unique distinction it gave to our homestead, so we named the place Buffalo Rock Farm.

I saw the rock-bleak and lonely as a cast-off friend-for the last time in 1920 when we were moving away. But I am sure it must still be in the same place today, for it weighed tons and what appeared to be a third of it was buried in the ground. I have seen five men sitting on its top at one time, and there was still room for at least two more.

Judging from the smooth-ground smaller rock nearby, as well as this giant one, they were left here by a melting glacier ages ago.

Old settlers told us that the rock got its name from the fact that buffaloes ranging the prairies in a not far-distant past would stop here to rub against the rock. In milling round and round it, their hoofs made a deep-rutted path, the imprint of which was still visible when I first visited the rock.

Not only did this rock make an interesting landmark, breaking the treeless monotony of the prairie, but to me it was a sort of monument to that bygone time before the white man invaded this part of Saskatchewan.

I loved to come to this rock, to lean against it and watch a gorgeous sunset or sunrise, and feel I was a mere speck in the immensity of space stretching away in every direction. This solid rock was something tangible for me to cling to in my strange new world as a homesteader's wife when loneliness tried to engulf me. If it could break its brooding silence what tales it might tell of roving Indians and buffalo hunters. Mute evidence of the past was the number of buffalo skulls which dotted our place.

Some moonlit night, when in a dreamy mood, I'd slip away to Buffalo Rock and from its top, watch and listen while a coyote on a knoll not far away sat and seemed to howl at the man-in-the-moon. Usually when our dog, Shep, heard the coyate's weird howls he would howl back in answer.

Although owners of our one-time homestead come and go, I have a feeling Buffalo Rock still broods over the land, majestic and silent as the Sphinx, while I, in nostalgic imagination, lean against its side, smelling wild roses and watching a carolling meadowlark wing into a summer sky "blue as an ocean's main". 